\title{
RB1 wt Allele
}

National Cancer Institute

\section{Source}

National Cancer Institute. RB1 wt Allele. NCI Thesaurus. Code C52102.

Human RB1 wild-type allele is located in the vicinity of $13 q 14.2$ and is approximately 178 $\mathrm{kb}$ in length. This allele, which encodes retinoblastoma-associated protein, is involved in the modulation of cellular proliferation. Mutation or deletion of the wild-type allele is a factor in the childhood onset of hereditary retinal cancer. 